Brit. J. Ophthal. (1954) 38, 46.

\title{
OCULAR PALSIES FOLLOWING RETROBULBAR INJECTION OF ACETYL CHOLINE FOR RETINAL ARTERIAL OCCLUSION*
}

BY

\author{
IAN W. PAYNE and HOWARD REED
}

London

WE have been able to trace the records of 73 cases of retinal arterial occlusion seen at the Royal Eye Hospital, 22 of which were treated by injecting acetyl choline. The results are shown in the Table.

TABLE

VISUAL RESULTS OF INJECTION OF ACETYL CHOLINE IN 22 CASES

\begin{tabular}{|c|c|c|c|c|c|c|}
\hline \multirow{2}{*}{$\begin{array}{l}\text { Case } \\
\text { No. }\end{array}$} & \multirow{2}{*}{ Age } & \multirow{2}{*}{$\begin{array}{l}\text { Delay in } \\
\text { Treatment } \\
\quad \text { (hrs) }\end{array}$} & \multirow{2}{*}{ Dose (g.) } & \multirow{2}{*}{ Route } & \multicolumn{2}{|c|}{ Visual Acuity } \\
\hline & & & & & Before & After \\
\hline $\begin{array}{l}\ddagger 1 \\
\vdots 2\end{array}$ & $\begin{array}{l}54 \\
64\end{array}$ & $\begin{array}{l}48 \\
60\end{array}$ & $\begin{array}{l}0.05 \\
0.05\end{array}$ & $\begin{array}{c}\text { Retrobulbar } \\
\text { Subconjunctival }\end{array}$ & $\begin{array}{c}6 / 12 \\
\text { Perception of }\end{array}$ & $\begin{array}{l}6 / 12 \\
6 / 60\end{array}$ \\
\hline 3 & 38 & 48 & 0.1 & Subcutaneous 2 & $\begin{array}{c}\text { No perception } \\
\text { of light }\end{array}$ & $\begin{array}{l}\text { No perception } \\
\text { of light }\end{array}$ \\
\hline 4 & 47 & Not known & 0.1 & Retrobulbar & ? Perception & $1 / 60$ \\
\hline 5 & 54 & Not known & 0.1 & Retrobulbar & Counting & Counting fingers \\
\hline $\begin{array}{l} \pm 6 \\
+7\end{array}$ & $\begin{array}{l}66 \\
70\end{array}$ & $\begin{array}{l}\text { Not known } \\
\text { Few }\end{array}$ & $\begin{array}{c}0.05 \\
\text { Moryl-0.00025 }\end{array}$ & $\begin{array}{c}\text { Retrobulbar } \\
\text { Subcutaneous } 3\end{array}$ & $\begin{array}{c}6 / 9 \\
\text { No perception } \\
\text { of light }\end{array}$ & $\begin{array}{c}6 / 9 \\
\text { No perception } \\
\text { of light }\end{array}$ \\
\hline $\begin{array}{r}+8 \\
9\end{array}$ & $\begin{array}{l}32 \\
53\end{array}$ & $\begin{array}{l}\text { Not known } \\
\text { Not known }\end{array}$ & $\begin{array}{l}0.05 \\
0.05\end{array}$ & $\begin{array}{l}\text { Retrobulbar } \\
\text { Retrobulbar }\end{array}$ & $\begin{array}{c}3 / 60 \\
\text { Counting } \\
\text { fingers }\end{array}$ & $\begin{array}{c}3 / 60 \\
\text { Counting fingers }\end{array}$ \\
\hline$* 10$ & 46 & 36 & 0.1 & Retrobulbar & $\begin{array}{l}\text { Counting } \\
\text { fingers }\end{array}$ & Counting fingers \\
\hline 11 & 77 & 12 & 0.05 & Retrobulbar & $\begin{array}{c}\text { Perception of } \\
\text { light }\end{array}$ & $6 / 12$ \\
\hline+12 & 42 & 24 & Moryl-0.00025 & Retrobulbar & $\begin{array}{l}\text { Counting } \\
\text { fingers }\end{array}$ & Counting fingers \\
\hline $\begin{array}{r}+13 \\
14 \\
+15\end{array}$ & $\begin{array}{l}64 \\
67 \\
63\end{array}$ & $\begin{array}{l}24 \\
12 \\
24\end{array}$ & $\begin{array}{c}\text { Moryl-0.00025 } \\
0.05 \\
0.05\end{array}$ & $\begin{array}{l}\text { Retrobulbar } \\
\text { Retrobulbar } \\
\text { Retrobulbar }\end{array}$ & $\begin{array}{c}3 / 60 \\
6 / 36 \\
\text { No perception }\end{array}$ & $\begin{array}{c}1 / 60 \\
6 / 36 \\
\text { No perception }\end{array}$ \\
\hline $\begin{array}{l}\$ 16 \\
17\end{array}$ & $\begin{array}{l}62 \\
67\end{array}$ & $\begin{array}{c}72 \\
1 \text { week }\end{array}$ & $\begin{array}{l}0.05 \\
0.05\end{array}$ & $\begin{array}{l}\text { Retrobulbar } \\
\text { Retrobulbar }\end{array}$ & $\begin{array}{c}6 / 9 \\
\text { Hand move- }\end{array}$ & Hand move- \\
\hline 18 & 66 & 96 & 0.05 & Subconjunctival & Hand move- & Hand move- \\
\hline $\begin{array}{r}19 \\
+20\end{array}$ & $\begin{array}{l}75 \\
42\end{array}$ & $\begin{array}{l}36 \\
72\end{array}$ & $\begin{array}{l}0.05 \\
0.05\end{array}$ & $\begin{array}{l}\text { Retrobulbar } \\
\text { Retrobulbar }\end{array}$ & $\begin{array}{c}6 / 60 \\
\text { Perception of }\end{array}$ & $\begin{array}{c}6 / 24 \\
\text { Perception of }\end{array}$ \\
\hline $\begin{array}{l}\ddagger 21 \\
* 22\end{array}$ & $\begin{array}{l}25 \\
33\end{array}$ & $\begin{array}{l}6 \\
1 \frac{1}{2}\end{array}$ & $\begin{array}{l}0.05 \\
0.05\end{array}$ & $\begin{array}{l}\text { Retrobulbar } \\
\text { Retrobulbar }\end{array}$ & $\begin{array}{c}6 / 9 \\
\text { No perception } \\
\text { of light }\end{array}$ & $\begin{array}{c}6 / 9 \\
\begin{array}{c}\text { Perception of } \\
\text { light }\end{array}\end{array}$ \\
\hline
\end{tabular}

*Received for publication June 26, 1953. 


\section{Results}

In only one case of the total of 73 cases was any improvement in vision recorded. Unfortunately the majority of these cases were not seen until the occlusion had been present for several days. The reason for this delay in seeking treatment is partly due to the fact that many of these patients had experienced recurrent attacks of transient loss of vision due to retinal artery spasm with complete recovery of vision. When the final occlusion occurred they awaited the accustomed return of sight for hours or days, so that by the time advice was sought the spasm had become an organic occlusion.

All that treatment can be expected to do is to relieve spasm, so that it is only in those few cases which are seen very early that visual improvement is possible. Even if sight returns after treatment it is difficult to decide whether the relaxation of the spasm was assisted by treatment or would have occurred spontaneously. More careful studies on the results of the use of the various vasodilators in early cases are needed before the value of treatment can be properly assessed.

\section{Case Reports}

Five cases examined by the authors developed ocular palsies after the retrobulbar injection of acetyl choline.

Case 10.- Here there was an almost complete external ophthalmoplegia, only the superior oblique being intact, and in addition a small fixed pupil and corneal anaesthesia; 4 weeks later the pupil was dilated and fixed, and the other signs unchanged. The external muscles recovered after 3 months, but 3 years afterwards the cornea was still anaesthetic, and the pupil still fixed and dilated. The corneal epithelium was intact despite the lack of sensation.

Case 14.-This patient showed a palsy of the superior rectus, inferior oblique, and levator palpebrae, with fixed dilated pupil and absent corneal sensation; 2 months later the ocular movements were normal, but there was still a moderate ptosis, and a tarsorrhaphy was performed to protect the anaesthetic cornea; 8 months after the injection the pupil and extra-ocular muscles appeared normal, but the corneal sensitivity was still impaired.

Case 19.-This patient showed ptosis and defective elevation of the eye, with corneal anaesthesia and a fixed semi-dilated pupil; 6 months later the corneal anaesthesia and pupillary paresis were unchanged, but there was some recovery of the extra-ocular muscles.

Case 20.-This patient developed an inferior rectus palsy, but was not seen again until 14 months after the injection, when the palsy had recovered.

Case 22.-A complete external rectus palsy developed within 2 hours of the injection, but there was no pupillary anomaly or interference with corneal sensitivity. There was a somewhat questionable visual improvement after the injection, but a paracentesis performed some 4 hours later was followed by objective improvement in the circulation, the patient counting fingers in the lower field. The palsy is now -5 weeks after the injection -showing signs of recovery.

\section{Aetiology of Ocular Palsy}

Several cases of retinal arterial occlusion treated by the injection of acetyl choline are recorded in the literature, but we have been unable to find any reference to ocular palsy complicating its use. 
In view of the very large numbers of retrobulbar anaesthetics which are administered in an eye hospital without this complication, we feel that these ocular palsies cannot be accounted for on the basis of mechanical trauma from the needle. It would therefore appear that they are due to the action of the acetyl choline itself, but the mechanism involved is obscure.

In no case was the fourth nerve involved, and it would appear that the acetyl choline injected into the muscle cone diffuses through this space, and may affect any of the nerves within it. It is interesting that the trigeminal nerve fibres supplying the cornea and the pupillomotor fibres seem to be damaged most severely. The loss of the consensual reflex in the affected eye indicates that the lesion is in the efferent pathway.

\section{Pharmacology}

Acetyl choline is the naturally occurring humoral transmitter at autonomic ganglia, parasympathetic nerve endings, and voluntary neuro-muscular junctions. It dilates arteries and arterioles, having its maximum effect in about half an hour, and it is for this reason that it is used in cases of arterial occlusion. Capillaries are not affected.

It also produces contraction of voluntary muscles by virtue of its physiological action on the motor end-plates of the nerves to these muscles. The extra-ocular muscles are unusually sensitive to its action. It has been shown experimentally that massive doses of acetyl choline may depolarize the muscle end-plate, thus causing temporary paralysis of the muscle, a blocking action which would be reinforced by the acetyl choline which is normally liberated at the nerve ending in constant but small amounts.

Acetyl choline is normally rapidly destroyed by cholinesterase in the tissues, and it is therefore difficult to explain the long duration of the palsies described. Further, the anomalous behaviour of the pupil in Case 10 and the anaesthesia of the cornea in three other cases remain unexplained.

\section{Summary}

Five cases are described in which ocular palsies followed the retrobulbar injection of acetyl choline. In each case the extra-ocular muscles were affected, and in three a pupillary palsy and anaesthesia of the cornea were also produced. The extra-ocular palsies show a tendency to slow recovery, but there has been no improvement in the corneal sensation, or pupillary reflexes.

We wish to thank the surgeons of the Royal Eye Hospital for allowing us access to their cases, and Professor Arnold Sorsby for his helpful criticism in the preparation of this paper. 